J. Lake Sci.(湖泊科学), 2009, 21(3): 387-394

http://www.jlakes.org. E-mail: jlakes@niglas.ac.cn

(C)2009 by Journal of Lake Sciences

\title{
广东流溪河水库湖沼学变量的时空动态特征
}

\author{
林国恩，望 甜，林秋奇，韩博平 ${ }^{* *}$ \\ (暨南大学水生生物研究所, 广州 510632)
}

摘 要: 流溪河水库是位于北回归线上的大型山谷型水库, 是一座典型的热带-亚热带过渡区水体. 为了解该水库的特点, 于 2006 年对水库的水文、营养盐状况及相关理化因子进行了逐月监测，对其主要的湖沼学变量的季节动态和空间分布进行了分析, 探讨了湖沼学特征和生态过程的主要驱动因子. 流溪河水库全年表层水温在 $14.9-31.6^{\circ} \mathrm{C}$ 之间, 水柱热分层开始于 3 月初, 一直 持续到 12 月, 呈单循环混合模式. 水库的水动力学主要受降水和水库用水的影响, 2006年全年降雨量为 $2960 \mathrm{~mm}$, 平均水力滞留 时间长 170d; 降雨量集中在丰水期(4-9 月), 导致丰水期水力滞留时间短(65d), 丰水期与枯水期水文水动力季节性差别显著, 水 文水动力学变化剧烈. 2006 年全年湖泊区的 TN、TP、Chl.a、SD 的平均值分别为 $0.66 \mathrm{mg} / \mathrm{L}, 0.016 \mathrm{mg} / \mathrm{L}, 2.2 \mathrm{mg} / \mathrm{m}^{3}, 3.1 \mathrm{~m}$, 指示该 水库为贫中营养型水体. N/P 的质量比为 41:1, DIN/DIP 的质量比为 $78: 1$, 说明该水库浮游植物生长在强烈的磷限制性水体中, 较 高的 N/P 比是由流域中热带-亚热带红壤中营养盐组成特点所决定. 营养盐、透明度和叶绿素 a 等变量的分布具有明显的时空异 质性, 丰水期初期(4-5 月)营养盐浓度显著地高于其它月份, 说明地表径流是输送营养盐人库的主要途径; 沿人库河流至水库大 坝方向, 营养盐和 Chl.a 具有递减规律, 即: 河流区>过渡区>湖泊区. 受季风的影响, 丰水期的降水集中加上水库的本身形态是 导致流溪河水库湖沼学特征呈显著的季节性和空间梯度的关键因素.

关键词: 湖沼学; 季节性; 空间质异性; 热带亚热带; 流溪河水库

\section{Spatial pattern and temporal dynamics of limnological variables in Liuxihe Reservoir, Guangdong}

LIN Guoen, WANG Tian, LIN Qiuqi \& HAN Boping

(Institute of Hydrobiology, Jinan University, Guangzhou 510632, P.R.China)

Abstract: Liuxihe Reservoir, located at the tropic of Cancer, is a large valley-type reservoir. In order to understand its limonological features, main limnological variables including hydrological and environmental factors were observed monthly in 2006. Surface water temperature ranged from $14.9^{\circ} \mathrm{C}$ to $31.6^{\circ} \mathrm{C}$. The thermal stratification was monomictic, initiating in the early March when the water temperature reached $20^{\circ} \mathrm{C}$, and lasting until December. The total precipitation in 2006 was $2960 \mathrm{~mm}$, but mainly distributed in wet season (from April to September). The mean water residence time was about 170 days, being more short in the flooding season (65 days). The mean concentrations of TN, TP, chlorophyll-a and SD were $0.66 \mathrm{mg} / \mathrm{L}, 0.016 \mathrm{mg} / \mathrm{L}, 2.2 \mathrm{mg} / \mathrm{m}^{3}$ and $3.1 \mathrm{~m}$, respectively, indicating that the reservoir was oligo-mesotrophic. Mass ratio of TN/TP is around 41, 78 for DIN/DIP. Both ratios were much higher than the Redfield ratio, and mean that growth of phytoplankton was strongly limited by phosphorus. The high N/P ratio was attributed to the tropical red soil containing rich iron. A distinct longitudinal pattern and seasonal variability in limnological variables were observed in this reservoir. At the beginning of wet season (April and May), all nutrient concentrations were significantly higher than other period. It confirmed that surface runoff was the main path for nutrient loading into the reservoir. The longitudinal pattern of nutrient and chlorophyll-a concentrations was typical as follows as riverine zone>transition zone>lacustrine zone, and the water transparency correspondingly showed an opposite one. High inflow with monsoon was the main driving force in seasonality of

* 国家自然科学联合基金项目(U0733007)资助. 2008-07-29 收稿; 2008-10-22 收修改稿. 林国恩, 男, 1983年生, 硕士研究 生; E-mail: lgen138@126.com.

** 通迅作者; E-mail: tbphan@jnu.edu.cn. 
limnological variables, and resulted finally in a significantly longitudinal gradient of these variables by interacting with the reservoir own morphology.

Keywords: Limnology; seasonality; heterogeneity; tropical and sub-tropical region; Liuxihe Reservoir

水库是一种半人工半自然的水体类型, 通常建于流域的上游, 库形狭长, 沿河道方向有明显的坡度, 最深处位于大坝附近. 由于对蓄水量的要求, 水库水面面积与流域面积之比一般在 1:20 至 1:100 之间, 远 大于天然湖泊的水面/流域面积比, 从而使流域特征(水量及化学)对水库水环境有着直接的影响 ${ }^{[1-2]}$. 水库 出库水量受人为调节, 输出水流的位置深度有多种选择. 水库水位的变化不仅受流域水文的影响, 同时 还与水库功能及调水模式有关. 由于库盆具有河流的特点, 在人库和出库水流剧烈变动时, 从人库河流 到大坝处的水动力学过程成为水质和生态系统结构动态变化的主要驱动力. 从人库河流到大坝处, 水库 可分为河流区、过渡区和湖泊区, 每一区域的水质和生态过程具有较大的差别 ${ }^{[3]}$.

由于库盆形态与水动力学调节方式的不同, 水库与天然湖泊在湖沼学特征上有很大差别. 由于世界 各国水库的建成时间都很短, 人们对水库生态系统的了解很有限, 数据的积累也很少, 对水库生态学还 未能形成较为系统的理论 ${ }^{[3-5]}$, 已有的水库生态学仅在欧洲高纬度地区有相对完善的研究 ${ }^{[6]}$. 目前水库水 质管理主要是借用高纬度地区湖泊研究的结果与管理经验 ${ }^{[7]}$.

华南地区是我国水库的主要分布区域之一, 地处热带至亚热带的过渡区，水库水资源在支撑区域发 展中发挥着重要的作用. 了解该地区水库的湖沼学特点, 对今后认识该地区水库生态系统的变化和有效 地进行水质管理是至关重要的. 流河溪水库是广州市的主要供水水源地, 该水库是一座大型的山谷型水 库, 位于北回归线上, 具有热带-亚热带的过渡区水体的典型湖沼学特点. 本文以流溪河水库为对象, 根据 2006 年对该水库的详细观测, 分析其湖沼学特征, 为同类水库的湖沼学研究和水质管理提供基础数据.

\section{1 材料与方法}

\section{1 流溪河水库概况}

流溪河水库是位于广东省从化市东北部 $\left(23^{\circ} 45^{\prime} \mathrm{N}, 113^{\circ} 46^{\prime} \mathrm{E}\right)$, 是北回归线北侧的一座大型峡谷型水库. 该水库建于 1956 年, 是以发电为主, 兼顾防洪灌溉等综合利用枢纽工程. 水库最大水深 $73 \mathrm{~m}$, 平均水深 $21.3 \mathrm{~m}$; 正常高蓄水位高程 $235 \mathrm{~m}$, 对应总库容 $3.25 \times 10^{8} \mathrm{~m}^{3}$; 死水位高程 $213 \mathrm{~m}$, 对应死库容 $0.86 \times 10^{8} \mathrm{~m}^{3}$. 水 库的出流主要为大坝的发电出流 (即发电厂的进水口), 进水口位于大坝右侧上游约 $300 \mathrm{~m}$ 处, 高程为 $206.5 \mathrm{~m}$. 水库的回水长度 $11.5 \mathrm{~km}$, 库盆坡度约 $0.45 \%$.
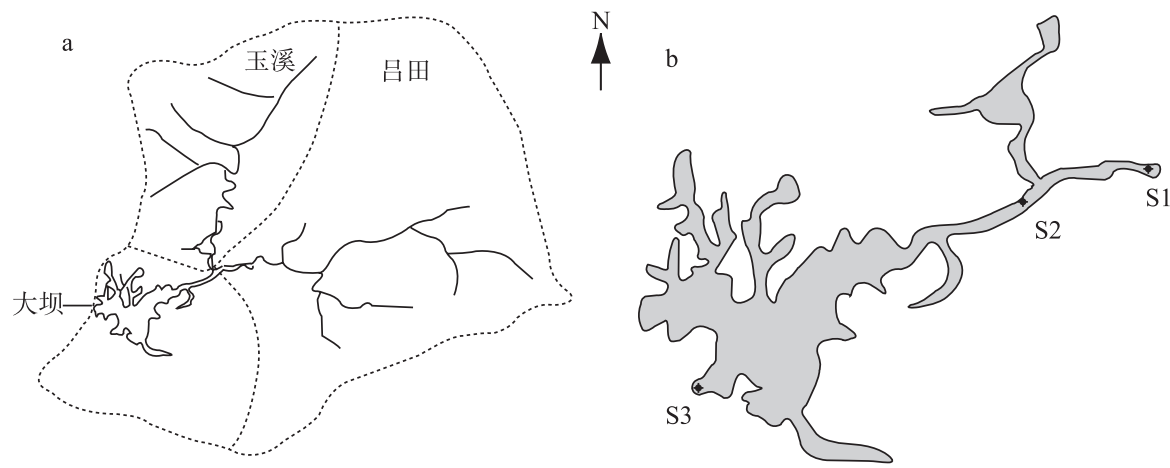

图 1 流溪河流域图与采样点分布

Fig.1 Catchment of Liuxihe Reservoir and the location of sampling sites

流溪河水库水系发源于吕田镇桂峰山的鲤鱼洞坳, 坝址以上干流河长 $37 \mathrm{~km}$. 水库总集水面积 $539 \mathrm{~km}^{2}$, 人库水流主要来自上游的 2 条支流: 吕田河与玉溪河. 其中吕田河为五级水系, 集雨面积 $264.4 \mathrm{~km}^{2}$; 玉溪河为四级水系，集水面积 $192.3 \mathrm{~km}^{2}$ ，吕田河和玉溪河集水面积占整个流域面积的 $85 \%$ ，汇 
集了流域的绝大部分人水水流. 水库水面面积约 $13 \mathrm{~km}^{2}$, 水库水面面积与流域面积之比约 1:41. 整个流域 内水土保持状况良好，人口少，人类活动强度低，坝址区域划为流溪河国家森林公园，是广州重要的旅 游休闲度假区.

\section{2 采样点设置与水质测定方法}

根据流溪河水库的形态结构和吞吐流特征, 水库按照河流区、过渡区和湖泊区进行采样点设置(采样 点设置见图 1b). 在支流吕田河处设置吕田采样点(S1: 代表河流区), 两条河流汇合处设置汇水采样点(S2: 代表过渡区)和大坝处设置大坝采样点(S3: 代表湖泊区), 2006 年每月采样一次.

用 YSI-85 型水质分析仪现场测定水温、溶解氧，萨氏盘测定透明度. 采取的水样, 按照国家标准方 法测定水样总磷 $(\mathrm{TP})$ 、正磷 $\left(\mathrm{PO}_{4}-\mathrm{P}\right)$ 、总氮 $(\mathrm{TN})$ 、硝氮 $\left(\mathrm{NO}_{3}-\mathrm{N}\right)$ 、亚硝氮 $\left(\mathrm{NO}_{2}-\mathrm{N}\right)$ 、氨氮 $\left(\mathrm{NH}_{4}-\mathrm{N}\right)^{[8]}$. 叶绿素 $\mathrm{a}$ 的浓度 (Chl.a) 测定采用改进的反复冻融-浸提法进行实验 ${ }^{[9]}$. 流溪河水库水文数据由流溪河水电站提供.

\section{2 结果与分析}

\section{1 水温的季节变化与垂直分层}

2006 年大坝采样点表层水温变幅为 $14.9-31.6^{\circ} \mathrm{C}$, 水体温度表现出明显的季节性变化: 6-9 月份表层 水温较高, 平均温度达到 $30^{\circ} \mathrm{C}$ 左右; 12 月至翌年 3 月处于低温期, 低于 $20^{\circ} \mathrm{C}$, 表层水温的最低温度出现 在 1、2 月份, 处于 $14-15^{\circ} \mathrm{C}$ (图 2a).
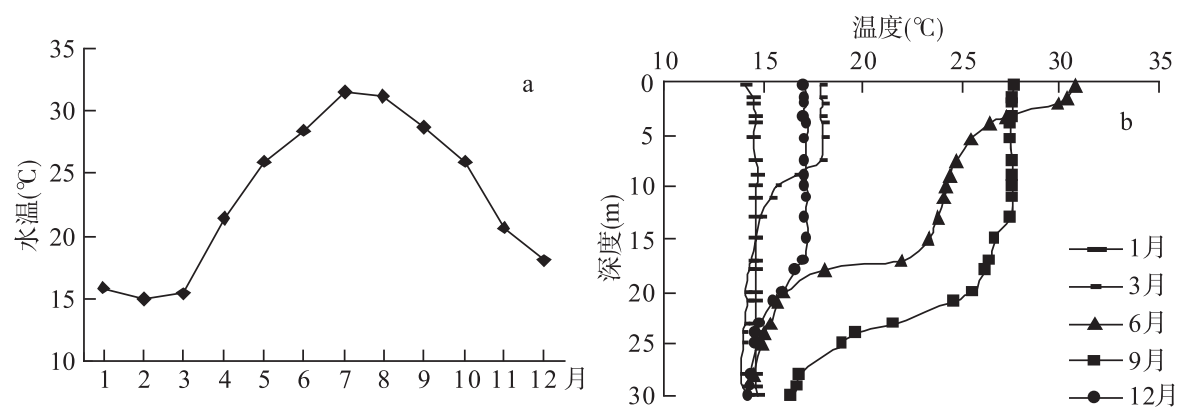

图 22006 年湖泊区的表层水温变化(a)和热分层(b)

Fig.2 Surface temperature variation (a) and thermal stratification (b) in the lacustrine zone

流溪河水库大坝的水温分层与混合的季节动态为典型的单混合水体. 图 $2 \mathrm{~b}$ 给出了 $1 、 3 、 6 、 9 、 12$ 月大坝区水体温度的垂直分布. 由于该水库是水体最大深度超过 $70 \mathrm{~m}$ 以上的大型深水水库, 表层 $30 \mathrm{~m}$ 以 下的水体温度全年保持在 $13-15^{\circ} \mathrm{C}$, 水温变化主要发生在 $30 \mathrm{~m}$ 以上水层. 1 月份是全年表层与深层水温温 差最小的月份, 温差小于 $2^{\circ} \mathrm{C}$; 随着气温回升, 3 月份开始形成明显的温跃层; 至 6 月份水温急剧升高, 在 浅层水体开始形成温差约 $5^{\circ} \mathrm{C}$ 的次温跃层; 9 月份是水体分层最充分、表层和底层水温相差最大的季节, 形成深度为 $20 \mathrm{~m}$, 温差为 $10^{\circ} \mathrm{C}$ 的温跃层; 9 月份后, 水体放热, 表层水体温度逐渐下降, 至 12 月份温跃层 消失.

\section{2 水文与水动力学}

2006 年降雨量为 $2960 \mathrm{~mm}$ ，属丰水年份(图 3a). 丰水期通常从 4 月份开始到 9 月份结束. 该年 4-9 月 的降雨量占年总降雨量的 76\%，其中 5-7 月 3 个月降雨量达 $1590 \mathrm{~mm}$, 为年总降雨量的 54\%; 其余月份为 枯水期, 枯水期总降雨量约 $860 \mathrm{~mm}, 1$ 月降雨量为 $39 \mathrm{~mm}$, 是降雨量最小的月份. 全年降雨主要集中在丰 水期.

2006年的水位高程波动区间为 222.7-235.2m, 最大和最小水位落差 $12 \mathrm{~m}$ (图 3b). 1-4月处于低水位期, 水位在 $225 \mathrm{~m}$ 上下波动; 随着雨季来临, 水库蓄水量增加, 5 月份水位开始上升, 6 月上旬很短的时间内, 水位急剧升高 $8 \mathrm{~m}$, 超过了大坝溢流堰高程 $235 \mathrm{~m}$, 水库出现溢流排水事件; 至 10 月份, 水位高程保持在 
$230 \mathrm{~m}$ 以上, 丰水期水库在高水位运行. 2006 年是丰水年, 年末水位比年初水位高 $4 \mathrm{~m}$ 左右, 水量收支处于 盈余状态.

流溪河水库 2006 年全年平均水力滞留时间为 $170 \mathrm{~d}$, 月均变幅为 43-380d(图 3c). 6 月份是人库和出库 水量最大的月份, 水力滞留时间仅 43d 为全年最小. 进入枯水期, 出水水量减少, 水力滞留时间逐渐延长, 11 月份水力滞留时间最长为 400d. 枯水期(10-3 月)平均水力滞留时间为 270d, 丰水期(4-9 月)平均水力 滞留时间为 65d. 丰、枯水期的水力滞留时间差异大，丰水期只有枯水期的 $1 / 4$.
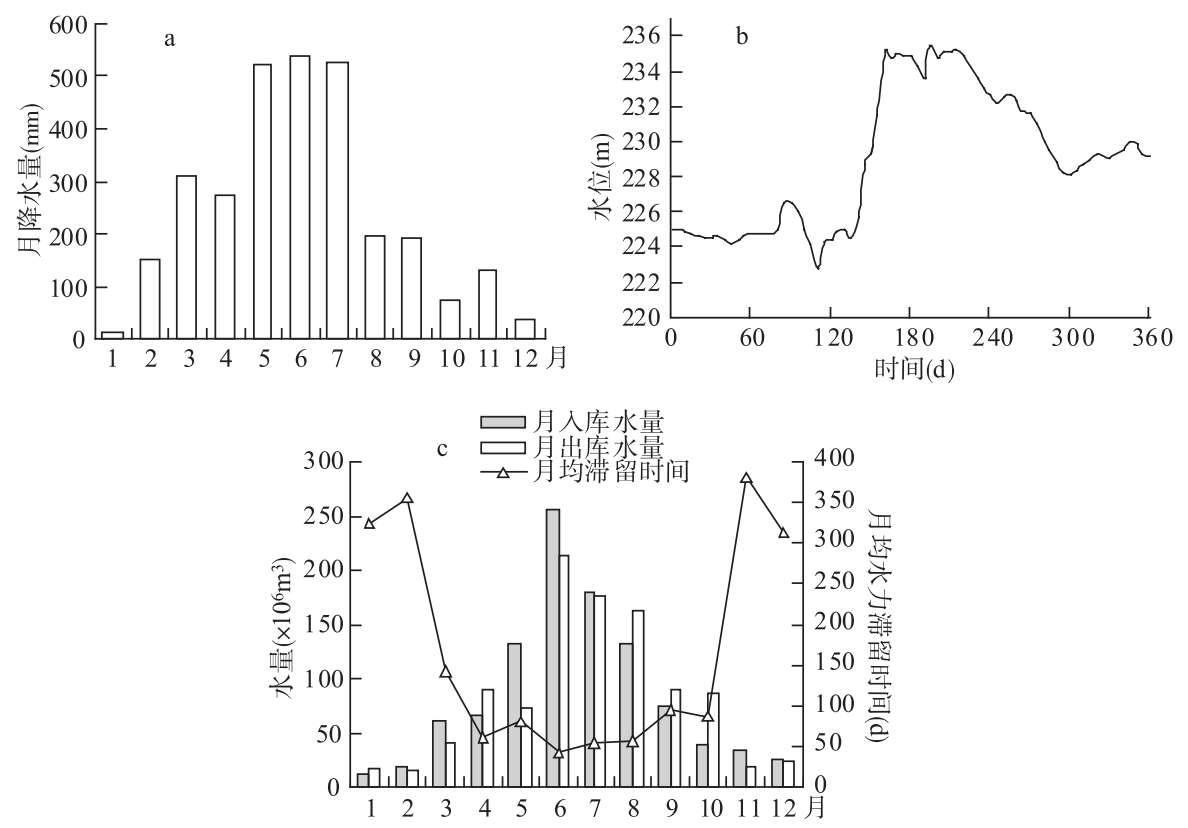

图 32006 年流溪河水库月降雨量(a); 水位周年变化(b)和人库-出库水量及水力滞留时间(c)

Fig.3 Monthly rainfall (a); annual variation of water level (b); inflow-outflow water volume; and corresponding residence time (c) in Liuxihe Reservoir, 2006

\section{3 营养盐组成和时空分布}

以湖泊区 (大坝采样点) 营养盐为例, 说明水库的营养盐状况 (图 4). TN 浓度为 $0.33-1.66 \mathrm{mg} / \mathrm{L}$, 年平均 $0.66 \mathrm{mg} / \mathrm{L}$; DIN(总溶解无机氮包括 $\mathrm{NO}_{3}-\mathrm{N} 、 \mathrm{NO}_{2}-\mathrm{N} 、 \mathrm{NH}_{4}-\mathrm{N}$ ) 浓度范围为 $0.12-0.57 \mathrm{mg} / \mathrm{L}$, 平均值 $0.31 \mathrm{mg} / \mathrm{L}$. 其中 $\mathrm{NO}_{3}-\mathrm{N}$ 占 DIN 的 $90 \%$, 是 DIN 的主要构成成份, DIN 占 TN 的 $60 \%$. TP 浓度范围 $0.006-0.027 \mathrm{mg} / \mathrm{L}$, 年 平均值 $0.016 \mathrm{mg} / \mathrm{L} ; \mathrm{PO}_{4}-\mathrm{P}$ 浓度为 $0.001-0.014 \mathrm{mg} / \mathrm{L}$, 年平均值为 $0.004 \mathrm{mg} / \mathrm{L} ; \mathrm{PO}_{4}-\mathrm{P}$ 占 $\mathrm{TP}$ 的 $25 \%$. 氮磷质 量比 $(\mathrm{N} / \mathrm{P})$ 为 41 , DIN/DIP 质量比为 78 .

3 个采样点的营养盐存在空间和季节分布差异: TN 最高值出现在 1 月份, 约 $1.5 \mathrm{mg} / \mathrm{L}$; 各点的最低值 出现在 7-8 月, 浓度范围 0.2-0.4mg/L; DIN 最高值出现在 4-6 月份, 浓度范围 0.5-0.7mg/L, 其它月份小 于 $0.4 \mathrm{mg} / \mathrm{L} ; \mathrm{TP}$ 的最高值出现在 4 月, 达 $0.14 \mathrm{mg} / \mathrm{L}$; 其余月份则明显较低, 处于 $0.01-0.05 \mathrm{mg} / \mathrm{L} ; \mathrm{PO}_{4}-\mathrm{P}$ 表 现为枯水期浓度稍高于丰水期, 各采样点一般小于 $0.006 \mathrm{mg} / \mathrm{L}$. 从季节变化看, 枯水期末期-丰水期前期 (3-5 月)是一年中营养盐浓度最高的时期; 丰水期中后期(6-9 月)是一年中营养盐浓度最低的时期. 营养 盐的空间分布特征总体呈：吕田(S1)>汇水(S2)>大坝(S3), 其中 TP 与 TN 的空间分布特征较明显, 而 $\mathrm{PO}_{4}-\mathrm{P}$ 与 $\mathrm{DIN}$ 的空间分布并不特别明显, 与影响这两个变量的因素较多有关.

\section{4 透明度和叶绿素 $\mathrm{a}$ 的时空分布}

2006 年透明度(SD)的季节分布特点是 2-6 月较低, 吕田、汇水和大坝一年中的 SD 最低值分别是 $0.9 \mathrm{~m} 、 0.8 \mathrm{~m}$ 和 $2 \mathrm{~m}$, 均出现在该时期; 丰水期中后期透明度明显升高, 8 月份是水库透明度最高的月份, 每 个采样点 SD 均超过 3m(图 5a). Chl.a 浓度在 4-6 月份较高, 汇水的 4 月份浓度为全年最高 $\left(15 \mathrm{mg} / \mathrm{m}^{3}\right)$, 各 
采样点 Chl.a 浓度在 4-6 月一般大于 $4 \mathrm{mg} / \mathrm{m}^{3}$; 丰水期 Chl.a 浓度高于枯水期. SD 空间分布特点是: 吕田 $(2 \mathrm{~m})<$ 汇水 $(2.3 \mathrm{~m})<$ 大坝 $(3.1 \mathrm{~m})$; Chl.a 空间分布特点是: 吕田>汇水>大坝(图 5b).
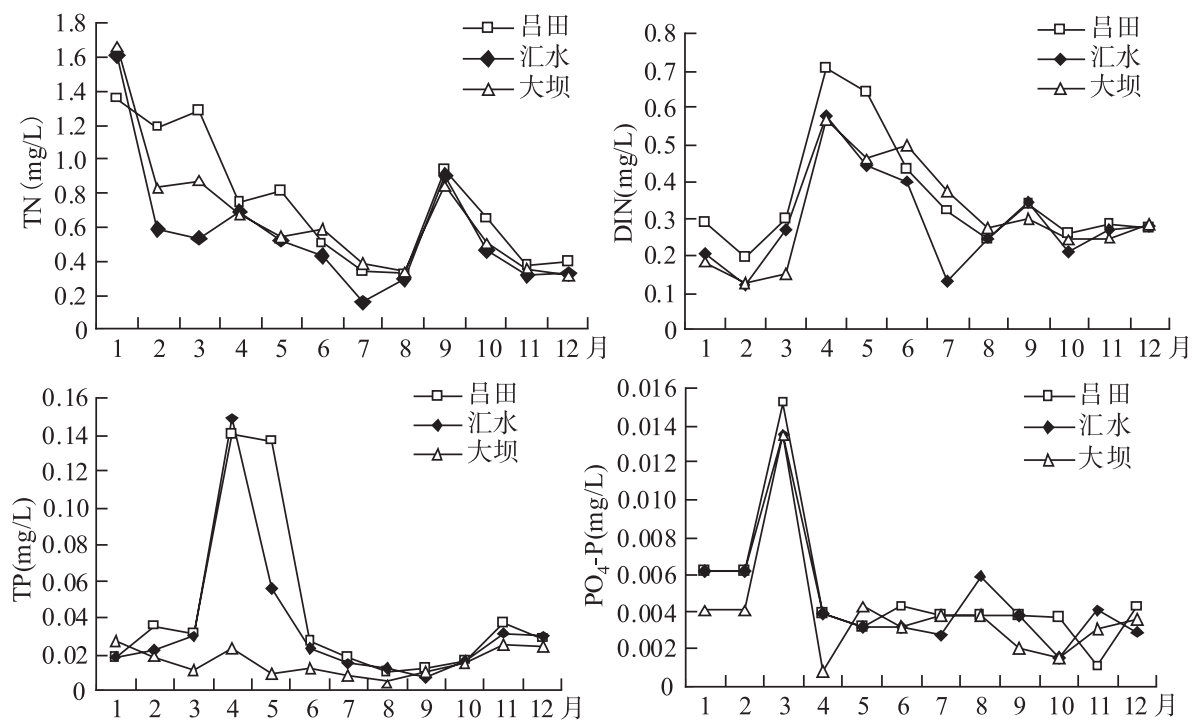

图 42006 年营养盐的时空分布

Fig.4 Temporal and spatial distribution of nutrients in 2006
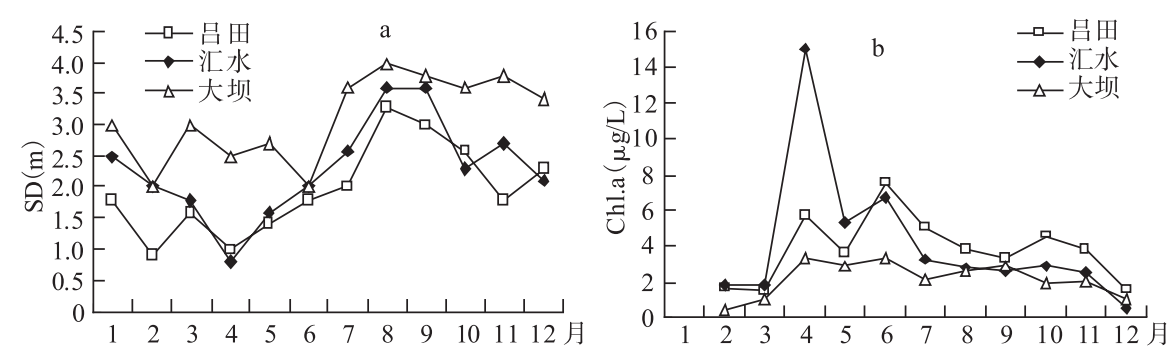

图 52006 年 SD(a)和 Chl.a(b)的时空分布(1 月份 Chl.a 数据缺失)

Fig.5 Temporal and spatial distribution of transparency (a) and chlorophyll-a concentration (b) in 2006 (Date was vacant in January)

\section{5 水质及水动力参数的相关性分析}

对 2006 年每个变量的月统计的基础上, 应用 SPSS13.0 软件, 对每月 3 个采样点的平均值进行相关 性分析. 从表 1 可以看出, DIN-TP、Chl.a-DIN、RT-T存在高相关性 $(P<0.01)$; Chl.a-TP、SD-TP 存在较 高的相关性 $(P<0.05)$. DIN 、TP 和 Chl.a 间存在正相关关系，说明了营养盐的同源性，主要来源于支流同期 的输人, 输人季节性强(丰水期初期), DIN 和 TP 是影响 Chl.a 的重要因素; 该水体 SD 和 TP 呈较高负相关 性, SD 与 Chl.a 的相关性并不强 $(P>0.05)$, 说明影响 SD 的主要因素不是 Chl.a, 而是携带营养物的外来悬 浮物颗粒物的输人.

\section{3 讨论}

流溪河水库是一座位于北回归线上的大型深水水库, 水文水动力学和主要水质变量的动态变化体 现了热带亚热带过渡区水库的特点. 受季风的影响, 用枯水期、丰水期或干、湿两期划分来分析主要湖 
沼学变量的动态更为合理. 流溪河水库是个典型的河道性的深水水体, 具有明显的人库河流, 湖沼学变 量的表现也具明显的空间异质性, 从人库河流区到大坝附近的湖泊区，具有较强的梯度分布，这种梯度 的形成是以水库的库形为基础, 以水动力学为主要驱动力的作用所形成. 与高纬度地区的水体相比, 季 节性的降水和水动力学过程是热带亚热带水库湖沼学特征的关键变量和控制因子 ${ }^{[10]}$.

表 1 流溪河水库 2006 年相关水质、水动力参数的相关性分析

Tab.1 Correlation analysis of water quality and hydrodynamic parameters in Liuxihe Reservoir, 2006

\begin{tabular}{|c|c|c|c|c|c|c|c|c|}
\hline & & TN & TP & DIN & $\mathrm{PO}_{4}^{-}-\mathrm{P}$ & Chl.a & $\mathrm{SD}$ & $\mathrm{T}$ \\
\hline \multirow[t]{2}{*}{ TP } & Pearson相关性 & 0.037 & & & & & & \\
\hline & 显著性 & 0.909 & & & & & & \\
\hline \multirow[t]{2}{*}{ DIN } & Pearson相关性 & -0.133 & $0.804^{* *}$ & & & & & \\
\hline & 显著性 & 0.680 & 0.002 & & & & & \\
\hline \multirow[t]{2}{*}{$\mathrm{PO}_{4}^{-}-\mathrm{P}$} & Pearson相关性 & 0.368 & -0.146 & -0.311 & & & & \\
\hline & 显著性 & 0.239 & 0.650 & 0.325 & & & & \\
\hline \multirow[t]{2}{*}{ Chl.a } & Pearson相关性 & -0.036 & $0.65^{*}$ & $0.862^{* *}$ & -0.396 & & & \\
\hline & 显著性 & 0.917 & 0.03 & 0.001 & 0.228 & & & \\
\hline \multirow[t]{2}{*}{ SD } & Pearson相关性 & -0.250 & $-0.677^{*}$ & -0.428 & -0.183 & -0.370 & & \\
\hline & 显著性 & 0.432 & 0.016 & 0.165 & 0.570 & 0.263 & & \\
\hline \multirow[t]{2}{*}{$\mathrm{T}$} & Pearson相关性 & -0.549 & -0.195 & 0.288 & -0.497 & 0.384 & 0.510 & \\
\hline & 显著性 & 0.065 & 0.543 & 0.364 & 0.100 & 0.244 & 0.091 & \\
\hline \multirow[t]{2}{*}{ RT } & Pearson相关性 & 0.281 & -0.132 & -0.535 & 0.073 & -0.587 & -0.105 & $-0.754^{* *}$ \\
\hline & 显著性 & 0.376 & 0.681 & 0.073 & 0.822 & 0.058 & 0.746 & 0.005 \\
\hline
\end{tabular}

** 显著性 $P<0.01 ; *$ 显著性 $P<0.05$.

\section{1 流溪河水库湖沼学的水动力学特征及季节动态}

流溪河全年水温分层时间长(3-12 月), 混合期短(1-2 月), 是典型单混合水体. 全年表层水温差为 $16^{\circ} \mathrm{C}$, 比温带地区的表层水温差要小得多. $30 \mathrm{~m}$ 以下的底层水温全年维持在 $14^{\circ} \mathrm{C}$ 左右, 这一水温要远高 于温带地区 (通常为 $4^{\circ} \mathrm{C}$ ). 由于全年底层的水温较高, 水柱上下层的最大水温差较小, 说明垂直分层的程 度要低于温带水体. 流溪河水库出现垂直分层的时间较早, 3 月份时, 表层水温接近 $20^{\circ} \mathrm{C}$ 时, 可以观察到 较明显的分层现象. 随水温增加温跃层深度增加, 在夏季出现次温跃层; 随混合深度增加, 次温跃层消 失, 温跃层深度和温差都增加; 随着气温的降低, 温跃层将消失, 水体达到重新混合状态. 在完全混合时 期, 水库水柱的水温在 $14^{\circ} \mathrm{C}$ 左右, 由于水温远高于温带水库完全混合的水温 $\left(4^{\circ} \mathrm{C}\right)$, 水柱的混合强度也低 于温带水体. 温跃层的变化也受水库出流的影响 ${ }^{[11]}$. 捷克的 Rimov 水库, 属于典型的温带峡谷型水库,

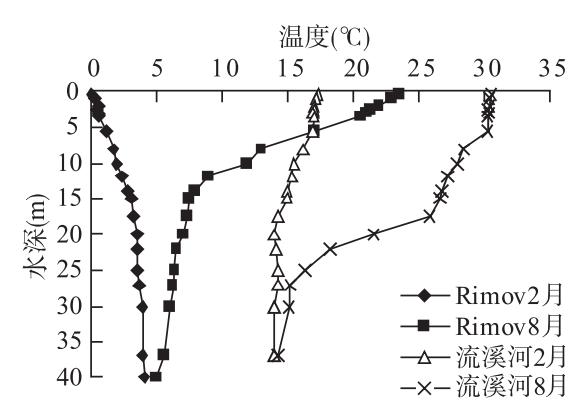

图 6 Rimov 水库和流溪河水库的水体热分层对比 Fig.6 Comparison of thermal stratification between Rimov Reservoir and Liuxihe Reservoir 水深最深达 $43 \mathrm{~m}^{[12]}$. 在该水库中, 水温周年变化幅度 通常在 $0-25^{\circ} \mathrm{C}$, 温差比热带、亚热带水库水温大. 图 6 为两个水库的特征季节(夏季和冬季)的热分层对比. Rimov 水库水体底层温度在 $4^{\circ} \mathrm{C}$ 左右, 冬季表水体温 度低于底层水体温度, 一年中会发生两次的表层、底 层水体翻转(turnover). 在流溪河水库中, 分层主要发 生在深水区(湖泊区), 为典型的单混合的热分层水体, 一年中不发生水体翻转. 在深水的分层水体上, 水柱 的垂直混合和翻转现象是表层和底层水体的营养盐交 换的重要过程 ${ }^{[13]}$, 相比温带或高纬度水体, 热带亚热 带深水水库的这种营养盐垂直的交换与输送强度要低 于温带水体, 这也从另一侧面说明该地区水库通过降 
水人库驱动力的纵向过程在水库生态系统中起着关键性的作用.

流溪河水库全年降雨量超过 2000mm，主要集中在季风期(4-9 月), 其中 5-7 这 3 个月降雨量约占全 年降雨量的一半, 降雨量大, 降雨集中, 枯水期与丰水期的差异较大是流溪河的降雨特点. 流溪河水库 具有防洪、发电和供水的功能, 供水主要是通过发电调节出库来控制, 降水和水库出水模式导致了水库 水力滞留时间具有强的季节变化. 2006 年, 月均滞留时间最短仅为 43 d 和最长达 380d. 3-4 月降雨少, 水 库为防洪开始泄水增加蓄水库容, 因此 4 月份的水位也是最低的. 5-8 月人库水量增加, 水库开始蓄水同 时水库的发电出流也增加, 起到调节水位的作用. 进人枯水期, 水库出水减少, 水力滞留时间大为增加, 是丰水期的 4 倍. 水力滞留时间(RT)与水温有显著的负相关性，也就是高温的丰水期水力滞留时间短. 由 于高水温与长滞留时间是维持水体浮游植物和浮游动物种群数量的关键因子 ${ }^{[14]}$, 而流溪河水库中水温与 滞留时间的相反的季节变化，丰水期集中降水导致的水文水动力学过程抑制了由于水温引起的季节过 程.

\section{2 水环境变量的时空异质性}

从营养盐和叶绿素 a 浓度来看, 流溪河水库是一个贫中营养的水体. 湖泊区全年 Chl.a 的平均值为 $2.2 \mathrm{mg} / \mathrm{m}^{3}, \mathrm{SD}$ 为 $3.1 \mathrm{~m}, \mathrm{TN}$ 为 $0.66 \mathrm{mg} / \mathrm{L}, \mathrm{TP}$ 为 $0.016 \mathrm{mg} / \mathrm{L}$. 氮磷比接近 $90: 1$, 远高于 Redfield 比值 $16: 1$, 说明 流溪河水库是强烈的磷限制性水体. 就一个水体而言, 水体中的营养盐来源主要依赖于外源性输人和内源 释放 ${ }^{[15-18]}$. 相对于湖泊而言, 水库底泥沉积底泥的内源污染负荷要低. 加上水柱的垂直混合强度低, 底层营 养盐向上的输送强度弱, 决定水体营养盐浓度的主要因素为外源输人. 流溪河水库的周边没有明显的点源 污染, 流域内的农业面源污染是影响水库水质的重要因素 ${ }^{[19-20]}$, 面源污染成为该水库的主要污染, 面源污 染人库则依赖于降水强度. 流溪河水库处于整个流溪河的流域上游, 土壤为典型热带亚热带红壤土, 含铁 高, 呈酸性, 对磷有很强的结合能力, 磷受到较强的结合是造成氮磷比高的原因. 水库集水区域森林覆盖率 较高, 这是水库维持低营养盐浓度的基本条件. 流溪河水库全年的平均滞留时间为 $170 \mathrm{~d}$, 在丰水期的滞留 时间只有 65d, 而丰水期是营养盐人库的主要时间, 该期间的短滞时间大大减少水库营养盐负荷的积累, 为 降低枯水期藻类生长的营养盐提供基础. 丰水期初期, 水库水位处于最低时期, 水力滞留时间相对较长, 人 库水量开始增加, 如 4 月份人库水量 $70 \times 10^{6} \mathrm{~m}^{3}$, 远高于 $1 、 2$ 月份的约 $20 \times 10^{6} \mathrm{~m}^{3}$, 说明降雨导致的冲刷作用 增强, 将整个枯水期所积累的面源污染在短时间内输送到水库, 导致水库在丰水期初期出现较高营养盐浓 度, 总磷、无机磷和溶解性无机氮的情况最为明显. 丰水期中后期, 如 6 月份人库水量约 $250 \times 10^{6} \mathrm{~m}^{3}$, 虽然 人库水量很大, 但经过丰水期初期的冲刷, 人库水流营养盐浓度明显降低了.

流溪河水库是一座典型的河道山谷水库, 坝址以上干流河长 $37 \mathrm{~km}$, 水库的回水长度 $11.5 \mathrm{~km}$, 库盆坡度 约 0.45\%. 吕田河(S3)至大坝区(S1)大约 $10 \mathrm{~km}, 3$ 个采样点上水质变量呈现较为明显的纵向空间梯度. 营养 盐浓度和叶绿素 a 浓度呈现一致空间分布，即从人库河流至大坝区呈递减少，而透明度呈增加的空间分布。 沿纵向梯度, 水库通常分为 3 个具有一定差别的区域: 河流区、过渡区和湖泊区 ${ }^{[2,21]}$. 河流区的浊度较高、 水流速度快, 具有河流的特点, 而湖泊区, 则接近湖泊的特征 ${ }^{[22]}$. 由于这种分区的主要驱动力是结合水库 的库形及坡度的人库水量, 水库的分区是动态的. 河流区和过渡区较为急速的水流特征, 如吕田河年平均 流速达到 $11.4 \mathrm{~m} / \mathrm{s}^{[23]}$, 加之丰水期初期由于水土流失导致水体悬浮颗粒物较多, 丰水期初期的透明度处于一 年中的最低值, 水体的高浊度导致水体较小的真光层. 因此, 吕田和汇水高的营养盐浓度并不一定带来高 的浮游植物生物量(Chl.a 浓度), 河流区和过渡区浮游植物生长受到水力条件变化和光照的影响 ${ }^{[23-24]}$. 随着 过渡区大量悬浮物的沉降及同时对营养盐的吸附作用, 湖泊区的浊度下降, 水体的光照条件提升而营养盐 浓度下降了, 大坝区浮游植物生物量(Chl.a 浓度)还是比吕田和汇水低, 大坝区的浮游植物生物量主要受到 营养盐限制. 在流溪河水库中, 分区最为明显的季节是丰水期初期和末期，也就是说在纵向水流在维持一 度流量是保证纵向梯度的存在的条件, 但相对而言, 丰水期初期的纵向梯度更为明显.

\section{4 参考文献}

[1] Thornton KW, Kimmel BL, Payne FE. Reservoir limnology: ecological perspectives. A Wiley-Interscience Publication, 1990: 16. 
[2] 林秋奇, 韩博平. 水库生态系统特征研究及其在水库水质管理中的应用. 生态学报, 2001, 21: 1034-1040.

[3] Straskraba M, Tundisi JG. Reservoir water quality management. International Environment Committee, 1999: 1-229.

[4] Kennedy RH. Considerations for establishing nutrient criteria for reservoirs. Lake Reserv Manag, 2001, 173: $175-187$.

[5] Han BP, Armengol J, Garcia JC et al. The thermal structure of Sau Reservoir: a simulation approach. Ecol Modell, 2000, 125: 109-122.

[6] Brierley B, Harper D. Ecological principles for management techniques in deeper reservoirs. Hydrobiologia, 1999, 395/396: 335-353.

[7] Lewis Jr WM. Basis for the protection and management of tropical lakes. Lake Reserv: Res Manag, 2000, 5: 35-48.

[8] 李秋华, 韩博平. 南亚热带调水水库春季浮游植物群落的结构与动态. 热带亚热带植物学报, 2007, 15(4): 294-300.

[9] 林少君, 贺立静, 黄沛生等. 浮游植物叶绿素 a 的提取方法比较与改进. 生态科学, 2005, 24: 9-11.

[10] An KG, Park SS. Indirect influence of the summer monsoon on chlorophyll-total phosphorus models in a reservoir: a case study. Ecol Modell, 2002, 152: 191-203.

[11] Casamithjana X, Serra T, Colomer J. Effects of the water withdrawal in the stratification patterns of a reservoir. Hydrobiologia, 2003, 504: 21-28.

[12] Brzakova M, Hejzlar J, Nedoma J. Phosphorus uptake by suspended and settling seston in a stratified reservoir. Hydrobiologia, 2003, 504: 39-49.

[13] 王雨春, 朱 俊, 马 梅等. 西南峡谷型水库季节性分层与水质的突发性恶化. 湖泊科学, 2005, 17(1): 54-60.

[14] Straskraba M. Retention time as a key variable of reservoir limnology. In: Tundisi JG, Straskraba M eds. Theoretical reservoir ecology and its applications, International Institute of Ecology. Brazilian Academy of Sciences and Backhuys Publishers, 1999: $385-410$.

[15] Caraco N, Cole JJ, Likens GE. A cross-system study of phosphorus release from lake sediments. comparative analysis of ecosystems: patterns, mechanisms and theories. New York: Springer-Verlag, 1991: 241-258.

[16] Granéli W. Internal phosphorus loading in Lake Ringsjön. Hydrobiologia, 1999, 404: 19-26.

[17] 范成新, 张 路, 杨龙元等. 湖泊沉积物氮磷内源负荷模拟. 海洋与湖沼, 2002, 33: 370-377.

[18] 秦伯强, 胡维平, 高 光等. 太湖沉积物悬浮的动力学机制及内源释放的概念性模型. 科学通报, 2003, 48: 760-768.

[19] Carpenter SR, Caraco NF, Correll DL et al. Nonpoint pollution of surface waters with phosphorus and nitrogen. Ecol Appl, 1998, 8: 559-568.

[20] Vanni MJ, Renwick WH, Headworth JL. Dissolved and particulate nutrient flux from three adjacent agricultural watersheds: A five-year study. Biogeochemistry, 2001, 54: 85-114.

[21] Thornton KW, Kennedy RH, Carrol JH et al. Reservoir sedimentation and water quality-Aheuristic model. In: Stefen HG ed. Proceedings of the symposium on surface water inpoundments. Amer Soc Civil Engr, NewYork, NY, 1981: 654-661.

[22] Grover JP, Chrzanowski TH. Limiting resources, disturbance, and diversity in phytoplankton communities. Ecol Monogr, 2004, 74: 533-551.

[23] 林秋奇, 胡 㓞, 韩博平. 流溪河水库水动力学对营养盐和浮游植物分布的影响. 生态学报, 2003, 23: 2278-2284.

[24] Reynolds CS. The ecology of freshwater phytoplankton. Cambridge: Cambridge University Press, 1984. 